\title{
Survival of a submarine canyon during long-term outbuilding of a continental margin
}

\author{
David Amblas', T.P. Gerber', B. De $\mathrm{Mol}^{3}$, R. Urgeles ${ }^{4}$, D. Garcia-Castellanos 5 , M. Canals 1 , L.F. \\ Pratson $^{6}$, N. Robb 7 , and Jason Canning 7 \\ 1 GRC Geociències Marines, Departament d'Estratigrafi a, Paleontologia i Geociències Marines, \\ Universitat de Barcelona, E-08028 Barcelona, Catalonia, Spain \\ ${ }_{2}$ Department of Geoscience, Indiana University of Pennsylvania, Indiana, Pennsylvania 15705, USA \\ ${ }_{3}$ GRC Geociències Marines, Parc Científi c de Barcelona, Universitat de Barcelona, E-08028 Barcelona, \\ Catalonia, Spain \\ 4Departament de Geologia Marina, Institut de Ciències del Mar, CSIC, E-08003 Barcelona, Catalonia, \\ Spain \\ 5Group of Dynamics of the Lithosphere, Institut de Ciències de la Terra 'Jaume Almera', CSIC, E-08028 \\ Barcelona, Catalonia, Spain \\ 6Division of Earth and Ocean Sciences, Duke University, Durham, North Carolina 27708, USA \\ 7BG Group, Thames Valley Park, Reading RG6 1PT, UK
}

\begin{abstract}
Net-depositional submarine canyons are common in continental slope strata, but how they survive and prograde on constructional margins is poorly understood. In this study we present fi eld evidence for the coevolution of a submarine canyon and the adjacent continental slope. Using a three-dimensional seismic data cube that images the Ebro margin (northwest Mediterranean), we identify a preserved canyon on a middle Pleistocene paleosurface and relate it directly to its expression on the present-day seafl oor. A subparallel stacking pattern of seismic refl ectors, similar to that seen between prograding clinoforms in intercanyon areas, is observed between the modern and paleocanyon thalwegs. The concavity of the modern long profi le differs from the convexconcave long profi le on the middle Pleistocene surface, suggesting a long-term change in canyon sedimentation. We interpret this change as a shift to a canyon dominated by turbidity currents from one strongly infl uenced by the pattern of sedimentation that built the open-slope canyon interfl uves. We fi nd support for our interpretation in previous studies of the Ebro margin.
\end{abstract}

\section{INTRODUCTION}

It has long been recognized that buried canyons exist in continental margin strata (Miller et al., 1987; Field and Gardner, 1990; Pratson et al., 1994). Increasingly available three-dimensional seismic data sets from deep-water settings around the world show that many modern submarine canyons have ancestors in the subsurface (e.g., Wonham et al., 2000; Deptuck et al., 2007; Straub and Mohrig, 2009). These observations have broadened our view of canyons as purely erosive features (Shepard, 1981) to one in which canyons may also be perpetuated through long-term margin construction, producing nested canyon successions. Several ideas have been put forward to explain the evolution of net-depositional canyons. Alternating periods of vertical fi 11 and incision (Wonham et al., 2000; Bertoni and Cartwright, 2005; Deptuck et al., 2007), the interplay of gravity fl ows and bottom currents (Zhu et al., 2010), and large sheet-like gravity fl ows (Straub and Mohrig, 2009) have all been proposed. Yet none of these models consider canyon evolution in light of well-established ideas for how margin clinoforms prograde. Gerber et al. (2009) tackled this problem by proposing a model for the long-profi le (i.e., along-thalweg depth profi le) shape of canyons based on the competition between turbidity currents and background sedimentation from the water column. The key element of their approach is the treatment of canyons on constructional margins as clinoforms which, together with intercanyon open slopes, defi ne the strike- 
averaged longprofi le shape of the margin. In this study we identify the seismic signature of canyon and intercanyon aggradation and progradation in a three-dimensional (3-D) seismic data set from the Ebro margin (EM) in the northwest Mediterranean Sea. We identify and map a preserved middle leistocene paleosurface representing one of the initial phases of the Ebro turbidite system. We then compare the morphology of a modern EM canyon to its ancestor morphology defi ned on the paleosurface. We discuss the canyon's evolution in light of what is known about the middle to late Pleistocene conditions along the margin. Our work adds the weight of fi eld evidence to the claim that submarine canyons and their interfl uves coevolve on constructional margins, an idea that can improve stratigraphic predictions for slope strata.

\section{GEOLOGICAL FRAMEWORK}

We limit our fi eld analysis to the region around the modern Orpesa Canyon on the EM (Fig. 1). This passive margin is characterized by a relatively wide continental shelf (70 km in the studied sector) built principally by sediment inputs from the Ebro River since the Middle Miocene (Urgeles et al., 2010, and references therein). The modern EM continental slope is densely canyonized, though few canyons exceed $500 \mathrm{~m}$ of relief in their upper courses. At the base of the slope some of the canyons grade into welldeveloped channel-levee complexes (Canals et al., 2000; Amblas et al., 2006).

The Orpesa Canyon is the southernmost modern tributary of the Valencia Trough turbidite systems. The concordance of the Orpesa Canyon long profi le with the modern Valencia Channel, the main conduit of the turbidite systems, suggests recent activity in the canyon (Amblas et al., 2011). Here we analyze its evolution from the mid-Pleistocene to the Holocene, a period of rapid high-amplitude sea-level fl uctuations and increased sedimentation along the EM (Nelson, 1990; Kertznus and Kneller, 2009).

\section{DATA SET AND METHODS}

Our study is based on a subset of a 3-D seismic survey from BG Group that covers $600 \mathrm{~km} 2$ around the Orpesa Canyon head and nearby continental shelf (Fig. 1). Seismic traces were processed to near zero phase and migrated with a single-pass 3-D pre-stack time migration. The seismic grid cells for the study are subsampled to $25 \times 25 \mathrm{~m}$. We consider the upper $0.15-1 \mathrm{~s}$ (two-way traveltime) beneath the modern shelf and slope. This interval includes almost the entire Pleistocene and Holocene succession with an average vertical resolution of $\sim 9 \mathrm{~m}$.

For the time-depth conversion in the distance-depth profi les we used the function detailed in Urgeles et al. (2010), calibrated from the sonic log in the Fornax-1 well (Fig. 1). To restore the paleobathymetry along these profi les we have removed the 2-D fl exural isostatic subsidence related to the weight of the increased water column and the weight of the sediment layer above the paleorelief (Allen and Allen, 2005). This is equivalent to a simplifi ed backstripping in which the tectonic subsidence is known to be negligible. For the $\mathrm{fl}$ exural calculations we use a pure elastic thin-plate approach (Turcotte and Schubert, 1982 ) with an equivalent elastic thickness of $15 \mathrm{~km}$ (Gaspar-Escribano et al., 2004) and a $1.92 \mathrm{~g} \mathrm{~cm}-3$ mean sediment density calculated from the nearby Fornax-1 exploration well data (adopted Young's modulus is $7 \times 10_{10} \mathrm{~Pa}$ ). To backstrip we also applied the sediment decompaction parameters (described in Urgeles et al., 2010), using a 0.479 initial porosity (dimensionless) and a 0.42 compaction coeffi cient $\left(\mathrm{km}_{-1}\right)$, both calculated from the Fornax-1 well data.

\section{ANALYSIS AND DISCUSSION}

\section{Horizon Defi nition}


The seismically imaged Holocene-Pleistocene strata in the study area consist of prograding shelf-margin clinoforms with canyons incising the outer shelf and slope (Fig. 2). The sigmoidal clinoforms consist of alternating moderate- to high-amplitude continuous refl ections with a highly progradational and aggradational geometry (Fig. 2B). In the upper interval these clinoform refl ectors are associated with divergent and transparent seismic facies. In strike section this interval is characterized by the appearance of the paleo-Orpesa Canyon, which is evidenced by nested high-amplitude seismic refl ectors (Fig. 2C).

The surface that separates the two seismically distinct intervals described here is most likely related to the fi rst Pleistocene glacioeustatic lowstand that approached shelf-edge depths, corresponding to Marine Isotopic Stage (MIS) 16 (Lisiecki and Raymo, 2005) and its successive transgression. This surface, here named Pt1, appears in strike profi les as a valley-shaped horizon that truncates the underlying refl ections and shows areas of localized incision (Fig. 2C). Several lowstands of comparable magnitude followed MIS 16 during the middle and late Pleistocene (Lisiecki and Raymo, 2005). The main EM outer shelf and upper slope depocenters record maximum rates of deposition during these periods, more than three times that of the Pleistocene highstands (Nelson, 1990). Our proposed age for Pt1 and the sedimentary units above is in agreement with the proposed age for the rapid development of the channellevee facies observed on the slope and base of slope (Field and Gardner, 1990). Similar results have been reported from the nearby Gulf of Lion prograding margin (Baztan et al., 2005). The average Quaternary sediment supply, including both highstand and lowstand periods, was more than double that of the Pliocene due to increased erosion caused by climatic deterioration (Nelson, 1990).

Just above surface Pt1 there is a mappable seismic surface that we name Pt2. We treat Pt2 as a reference stratigraphic horizon and use it to produce a detailed map of the mid-Pleistocene Orpesa Canyon and its surrounding margin (Fig. 3A; Fig. DR1 in the GSA Data Repository 1 ). We choose this surface because (1) it can be correlated through most of the area of interest and (2) Orpesa Canyon is well developed by Pt2 time but shows only incipient form at Pt1 time. The mapping of Pt 2 was carried out on a line by line basis, using a combination of seismic cross sections, time and horizon slices, and 3-D visualization. Slope, root mean square, and coherency-dip seismic attributes (Fig. DR1) have been used for stratigraphic interpretation and canyon characterization.

\section{Modern versus Middle Pleistocene Physiography}

The modern Orpesa Canyon is $68 \mathrm{~km}$ long, has a relatively narrow and $\mathrm{fl}$ at-fl oored thalweg (maximum width $700 \mathrm{~m}$ ), and follows a moderately sinuous course (sinuosity index 1.10) (Fig. 1). The middle and lower courses show well-developed channel-levee complexes and the upper course displays steep (locally to $40^{\circ}$ ) gullied $\mathrm{fl}$ anks. Maximum canyon downcutting is $450 \mathrm{~m}$ and shelf indention is $\sim 8 \mathrm{~km}$.

The morphology of the modern upper canyon is strikingly similar to its mid-Pleistocene ancestor, showing that canyon physiography is broadly maintained through time (Figs. 2A and 3A). The Pt2 Orpesa Canyon head displays a meandering thalweg $\mathrm{fl}$ anked by steep walls with gully development (Fig. 3 A; Fig. DR1). The paleocanyon head is incised $\sim 9 \mathrm{~km}$ into the mid-Pleistocene continental shelf. Along with overall margin progradation, the canyon-channel system has migrated in time slightly to the northeast (Fig. DR2). This is a general trend seen in all the EM canyons (Field and Gardner, 1990; Kertznus and Kneller, 2009).

\section{Long-Term Canyon Construction}

The way EM canyons survive during margin progradation is evident in the seismic architecture between Pt2 and the seafl oor. Seismic cross sections show canyon-fi 11 deposits with nested high-amplitude seismic refl ectors (Fig. 2C). More interesting is that the seismic profi le coupling the modern Orpesa thalweg with the Pt2 thalweg reveals a general subparallel stacking pattern of moderate- to high- 
amplitude seismic refl ections (Fig. 2D), similar to the prograding clinoform architecture observed in the same chronostratigraphic interval outside the canyon (Fig. 2B). From this we can only conclude that over the past $0.5 \mathrm{~m} . \mathrm{y}$. the canyon has been a site of net sediment storage, despite periods of erosion and transient disequilibrium associated with sea-level lowstands.

Insight into the processes responsible for sediment storage in Orpesa Canyon can be gained by comparing its Pt2 long profi le with its presentday form (Fig. 3). While the backstripped Pt2 long profi le clearly shows a sigmoidal (convex-concave) curvature, the modern Orpesa long profi le displays a positive (concave up) curvature (Fig. 3B) similar to all Valencia Trough turbidite system modern canyons along the EM (Amblas et al., 2011). Following the model of Gerber et al. (2009), we interpret this change in long-profi le curvature as a change in the relative importance of background sedimentation, construed here as a mix of hemipelagic settling and deposition from weak shelf gravity $\mathrm{fl}$ ows that dissipate below wave base (sensu Parker, 2006). The mid-Pleistocene (Pt2) canyon long profi le resembles the interfl uve long profi le, and its convex reach is located near the clinoform infl ection point that defi nes the midPleistocene shelf break. This suggests that the Pt2 canyon and interfl uve were shaped by a similar pattern of background sedimentation (Fig. 3C). In contrast, we think that long-profi le concavity in the modern canyon is a consequence of a shift in the relative importance of turbidity current sedimentation in the canyon. Long-profi le concavity is expected in submarine canyons and channels shaped by sediment transport in sustained, fully developed turbidity currents (Mitchell, 2005; Gerber et al., 2009; Spinewine et al., 2011), and will thus characterize equilibrium long profi les under conditions of sediment bypass or net deposition, the latter balancing subsidence and/or causing basinward progradation.

The shift in dominant canyon processes that we infer is not the result of a single highstand to lowstand transition. Rather, we argue for a longterm increase in the relative importance of turbidity currents in Orpesa Canyon over the past 0.5 m.y., and fi nd evidence for such a change in previous work on the EM. The progressive steepening of the EM observed in the intercanyon clinoform profi les (Fig. 3B) was also reported by Kertznus and Kneller (2009), who inferred that such steepening increased the frequency of mass wasting and resulting sediment gravity fl ows through time (Kertznus and Kneller, 2009; Petter et al., 2011). If true, the frequency of turbidity currents sourced from the upper reaches of Orpesa Canyon likely increased. The comparison between $\mathrm{Pt} 2$ and the present seafl oor also reveals a gradual loss of relief in the canyons adjacent to Orpesa Canyon as they were buried (Fig. DR2). The change from numerous, closely spaced canyons to fewer, more widely spaced and larger canyons through the middle and late Pleistocene is observed along the entire EM (Kertznus and Kneller, 2009). We think that this trend refl ects the progressive capture of cross-shelf fl ows by the surviving canyons, increasing their effective shelf drainage area and thus the size and frequency of downcanyon $\mathrm{fl}$ ows. Taken together, more favorable conditions for $\mathrm{fl}$ ow generation within the canyon and a larger shelf area over which shelf $\mathrm{fl}$ ows are captured by the canyon support our long profi le-based inference.

\section{CONCLUSIONS}

Field and Gardner (1990) fi rst recognized stacked Pleistocene submarine canyons on 2-D seismic profi les of the Ebro margin upper slope. In this paper we present a 3-D seismic study on the morphology and architecture of a single EM canyon through its evolution from the mid-Pleistocene to the present. By mapping a regional seismic refl ection that locally defi nes the paleocanyon surface, we are able to compare the canyon's evolution to that of its interfl uves. Seismic refl ectors beneath both the modern canyon thalweg and its bounding interfl uves show progradation and aggradation, indicating margin-wide sediment storage on the continental slope over the past $0.5 \mathrm{~m}$.y. A comparison of the modern canyon long profi le with the buried long profi le restored to paleobathymetry demonstrates a clear change in dominant sedimentary processes in the canyon. Our study motivates broadened thinking about canyon evolution on prograding margins and demonstrates how buried canyon long profi les can be used to infer past conditions on the margin. 


\section{ACKNOWLEDGMENTS}

Three-dimensional seismic data were provided by BG Group, and we thank them for permission to publish this paper. The work was funded by Ministerio de Ciencia e Innovación (MICINN) through project EDINSED3D (CTM200764880/MAR). Amblas acknowledges additional fi nancial support from the European Commission Seventh Framework Programme through project HERMIONE (EC contract 226354), and from the Spanish I+D+I projects GRACCIE-CONSOLIDER (CSD2007-00067), DOS MARES (CTM2010-21810-C03-01/ MAR), and TopoMed (CGL2008-03474-E/BTE). We acknowledge support from SeismicMicrotechnologies for Kingdom Suite Educational License Grant and to dGB Earth Sciences for providing access to Opendtect software. The Generalitat de Catalunya is acknowledged for support through Grups de Recerca Consolidats grants 2009-SGR-146 and 2009-SGR-1305. We also thank Angelo Camerlenghi and Matthew A. Wolinsky for valuable discussions on earlier stages of this study, and David Mohrig, Rob Gawthorpe, and an anonymous reviewer for constructive reviews that helped shape and improve the manuscript.

\section{REFERENCES CITED}

Allen, P.A., and Allen, J.R., 2005, Basin analysis: Principles and applications (second edition): Oxford, Blackwell Scientifi c Publications, $549 \mathrm{p}$.

Amblas, D., Canals, M., Urgeles, R., Lastras, G., Liquete, C., Hughes-Clarke, J.E., Casamor, J.L., and Calafat, A.M., 2006, Morphogenetic mesoscale analysis of the northeastern Iberian margin, NW Mediterranean basin: Marine Geology, v. 234, p. 3-20, doi:10.1016/j.margeo.2006.09.009.

Amblas, D., Gerber, T.P., Canals, M., Pratson, L.F., Urgeles, R., Lastras, G., and Calafat, A.M., 2011, Transient erosion in the Valencia Trough turbidite systems, NW Mediterranean Basin: Geomorphology, v. 130, p. 173-184, doi:10.1016/j.geomorph.2011.03.013.

Baztan, J., Berné, S., Olivet, J.L., Rabineau, M., Aslanian, D., Gaudin, M., Réhault, J.P., and Canals, M., 2005, Axial incision: The key to understand submarine canyon evolution (in the western Gulf of Lion): Marine and Petroleum Geology, v. 22, p. 805-826, doi:10.1016/j.marpetgeo.2005.03.011.

Bertoni, C., and Cartwright, J., 2005, 3D seismic analysis of slope-confi ned canyons from the Plio-Pleistocene of the Ebro Continental Margin (Western Mediterranean): Basin Research, v. 17, p. 43-62, doi:10.1111/j.1365 2117.2005.00254.x.

Canals, M., Casamor, J.L., Urgeles, R., Lastras, G., Calafat, A.M., De Batist, M., Masson, D., Berné, S., Alonso, B., and Hughes-Clarke, J.E., 2000, The Ebro continental margin, Western Mediterranean Sea: Interplay between canyonchannel systems and mass wasting processes, in Nelson, C.H., and Weimer, P., eds., Deep-water reservoirs of the world: Houston, Texas, GCSSEPM

Foundation 20th Annual Research Conference, p. 152-174.

Deptuck, M.E., Sylvester, Z., Pirmez, C., and O’Byrne, C., 2007, Migrationaggradation history and 3-D seismic geomorphology of submarine channels in the Pleistocene Benin-major Canyon, western Niger Delta slope: Marine and Petroleum Geology, v. 24, p. 406-433, doi:10.1016/j.marpetgeo.2007.01.005.

Field, M.E., and Gardner, J.V., 1990, Pliocene-Pleistocene growth of the Rio Ebro margin, northeast Spain: A prograding-slope model: Geological Society of America Bulletin, v. 102, p. 721-733, doi:10.1130/0016-7606(1990) $102<0721$ :PPGOTR $>2.3 . \mathrm{CO} ; 2$.

Gaspar-Escribano, J.M., Garcia-Castellanos, D., Roca, E., and Cloetingh, S., 2004, Cenozoic vertical motions of the Catalan Coastal Ranges (NE Spain): The role of tectonics, isostasy, and surface transport: Tectonics, v. 23, TC1004, doi:10.1029/2003TC001511.

Gerber, T.P., Amblas, D., Wolinsky, M.A., Pratson, L.F., and Canals, M., 2009, A model for the long-profi le shape of submarine canyons: Journal of Geophysical Research, v. 114, F03002, doi:10.1029/2008JF001190.

Kertznus, V., and Kneller, B., 2009, Clinoform quantifi cation for assessing the effects of external forcing on continental margin development: Basin Research, v. 21, p. 738-758, doi:10.1111/j.1365-2117.2009.00411.x. 
Lisiecki, L.E., and Raymo, M.E., 2005, A Pliocene-Pleistocene stack of 57 globally distributed benthic d18O records: Paleoceanography, v. 20, PA1003, doi:10.1029/2004PA001071.

Miller, K.G., Melillo, A.J., Mountain, G.S., Farre, J.A., and Poag, C.W., 1987, Middle to late Mio cene canyon cutting on the New Jersey continental slope: Biostratigraphic and seismic stratigraphic evidence: Geology, v. 15, p. 509- 512, doi:10.1130/0091-7613(1987)15<509:MTLMCC >2.0.CO;2.

Mitchell, N.C., 2005, Interpreting long-profi les of canyons in the USA Atlantic continental slope: Marine Geology, v. 214, p. 75-99, doi:10.1016/j.margeo .2004.09.005.

Nelson, C.H., 1990, Estimated post-Messinian sediment supply and sedimentation rates on the Ebro continental margin: Marine Geology, v. 95, p. 395-418, doi:10.1016/0025-3227(90)90126-5.

Parker, G., 2006, Theory for a clinoform of permanent form on a continental margin emplaced by weak, dilute muddy turbidity currents, in Parker, G., and Garcia, M., eds., River, coastal, and estuarine morphodynamics: Proceedings of the 4 th International Association of Hydraulic Engineering and Research Symposium on River, Coastal, and Estuarine Morphodynamics, p. 553-561.

Petter, A.L., Wonsuck, K., Muto, T., and Steel, R.J., 2011, Clinoform quantifi cation for assessing the effects of external forcing on continental margin development: Basin Research, v. 23, p. 118-121, doi:10.1111/j.13652117.2010.00472.x.

Pratson, L.F., Ryan, W.B.F., Mountain, G.S., and Twhichell, D.C., 1994, Submarine canyon initiation by downslopeeroding sediment $\mathrm{fl}$ ows: Evidence in late Cenozoic strata on the New Jersey continental slope: Geological Society of America Bulletin, v. 106, p. 395-412, doi:10.1130/0016-7606(1994)106<0395 :SCIBDE >2.3.CO;2.

Shepard, F.P., 1981, Submarine canyons; multiple causes and long-time persistence: American Association of Petroleum Geologists Bulletin, v. 65, p. 1062-1077.

Spinewine, B., Sun, T., Babonneau, N., and Parker, G., 2011, Self-similar long profi les of aggrading submarine leveed channels: Analytical solution and its application to the Amazon channel: Journal of Geophysical Research, v. 116, F03004, doi:10.1029/2010JF001937.

Straub, K.M., and Mohrig, D., 2009, Constructional canyons built by sheet-like turbidity currents: Observations from offshore Brunei Darussalem: Journal of Sedimentary Research, v. 79, p. 24-39, doi:10.2110/jsr.2009.006.

Turcotte, D.L., and Schubert, G., 1982, Geodynamics: Application of continuum physics to geological problems: New York, John Wiley and Sons, $450 \mathrm{p}$.

Urgeles, R., Camerlenghi, A., Garcia-Castellanos, D., De Mol, B., Garcés, M., Vergés, J., Haslam, I., and Hardman, M., 2010, New constraints on the Messinian sealevel drawdown from 3D seismic data of the Ebro Margin, western Mediterranean: Basin Research, v. 23, p. 123-145, doi:10.1111/j.1365 -2117.2010.00477.x.

Wonham, J.P., Jayr, S., Mougamba, R., and Chuilon, P., 2000, 3D sedimentary evolution of a canyon fi 11 (Lower Miocene-age) from the Mandrove Formation, offshore Gabon: Marine and Petroleum Geology, v. 17, p. 175197,doi:10.1016/S0264-8172(99)00033-1.

Zhu, M., Graham, S., Pang, X., and McHargue, T., 2010, Characteristics of migrating submarine canyons from the middle Miocene to present: Implications for paleoceanographic circulation, northern South China Sea: Marine and Petroleum Geology, v. 27, p. 307-319, doi:10.1016/j.marpetgeo.2009.05.005. 


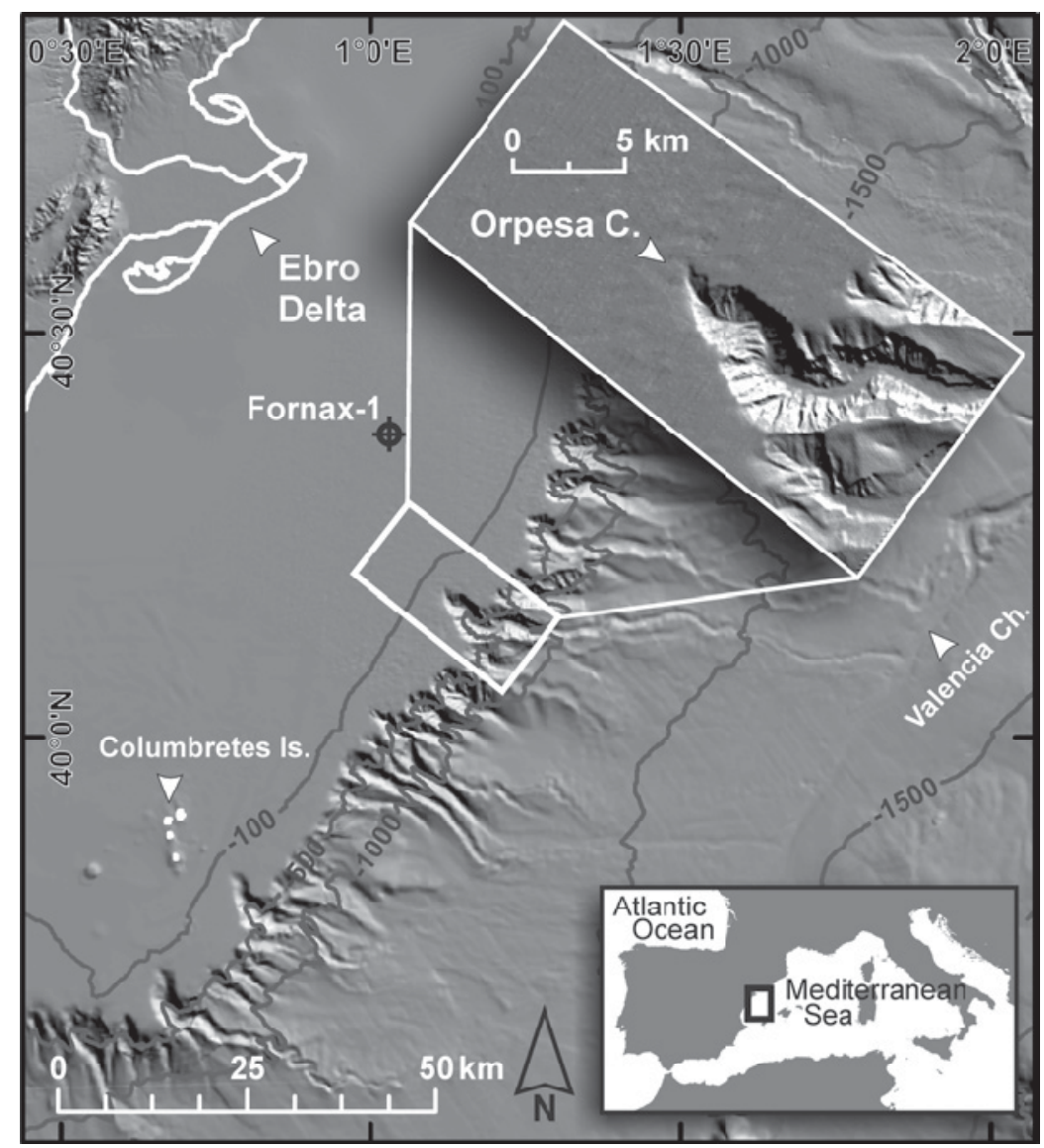

Figure 1. Digital terrain model of Ebro continental margin built from three-dimensional (3-D) seismic data, multibeam bathymetry, and global digital databases. White box encloses area of 3-D seismic survey examined in this study. C.-canyon; Ch.-channel; Is.-island. 

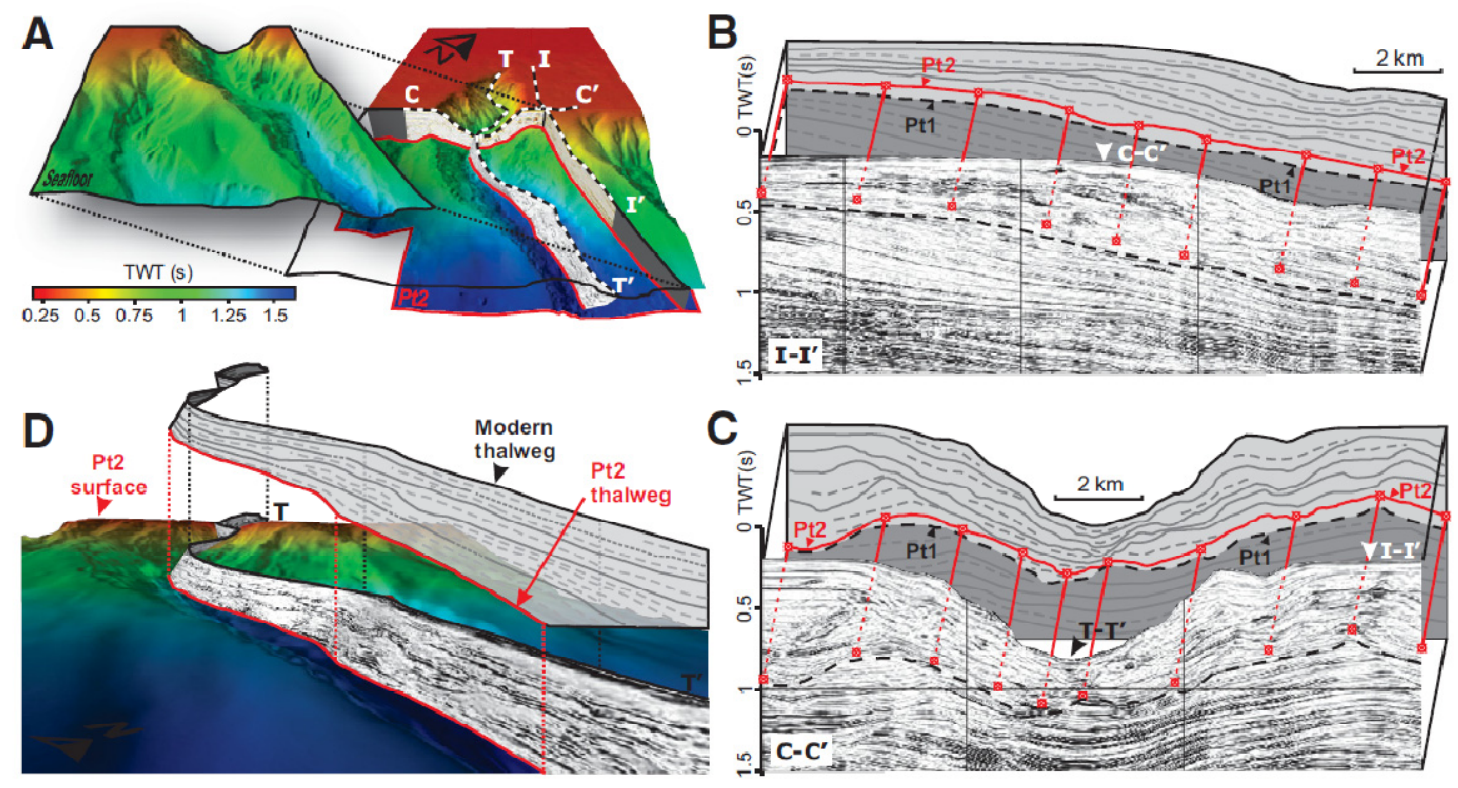

Figure 2. A: Three-dimensional (3-D) view of stacked modern and mid-Pleistocene (Pt2) surfaces around Orpesa Canyon along with locations of seismic profi les, shown as white dashed lines. TWT-two-way traveltime. B: View along bounding interfl uve. C: View across canyon. D: View between Pt2 and modern Orpesa thalweg. Interfl uve profi le displays progradation and aggradation of shelf-margin clinoforms, while canyon profi le illustrates nested stack of canyon refl ectors beneath presentday canyon. Seismic profi le between Pt2 and modern Orpesa thalweg, in 3-D view from southeast $D$, shows general subparallel stacking pattern of seismic refl ections, similar to prograding clinoform architecture observed within same interval in open slope adjacent to canyon 

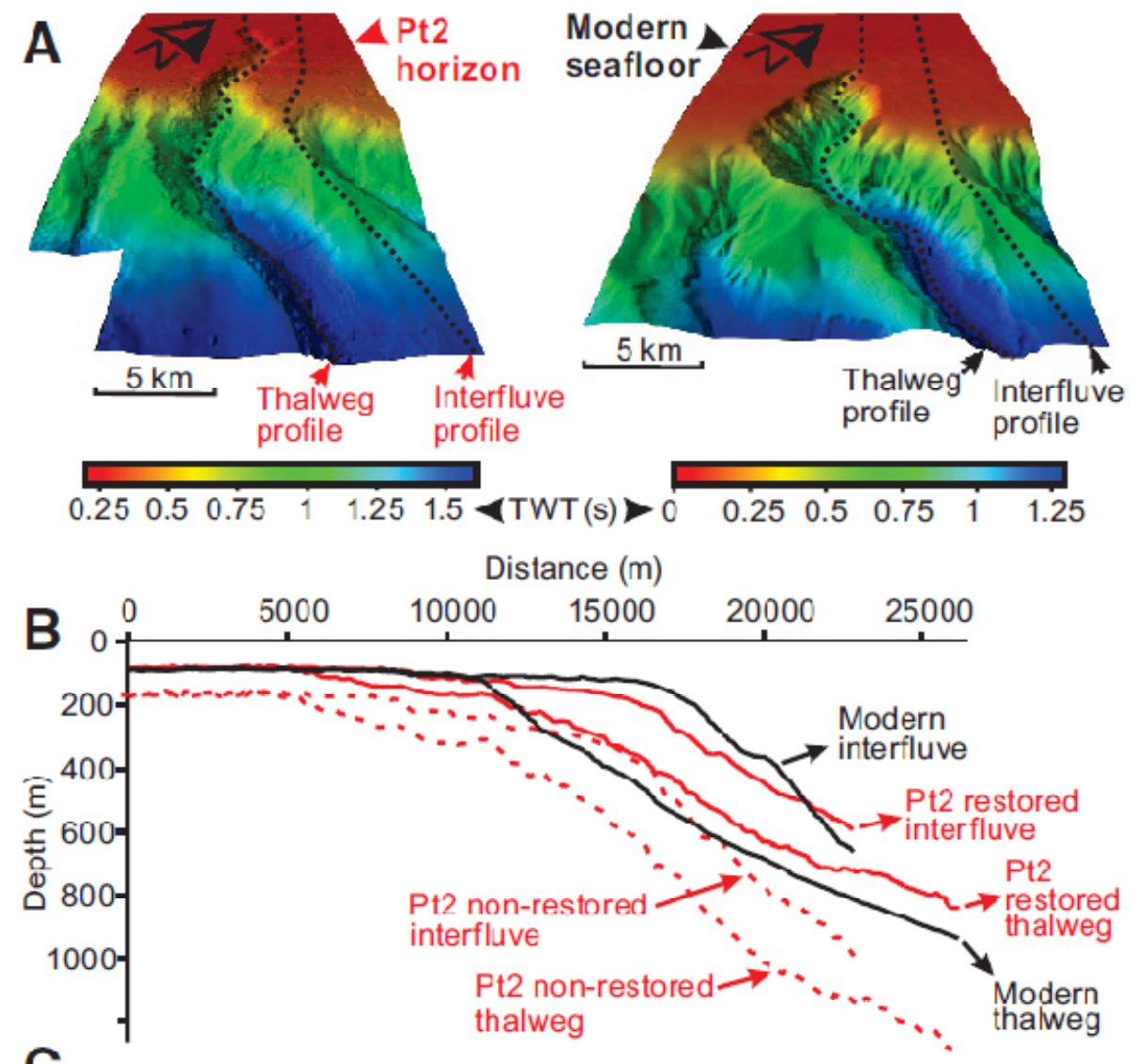

C
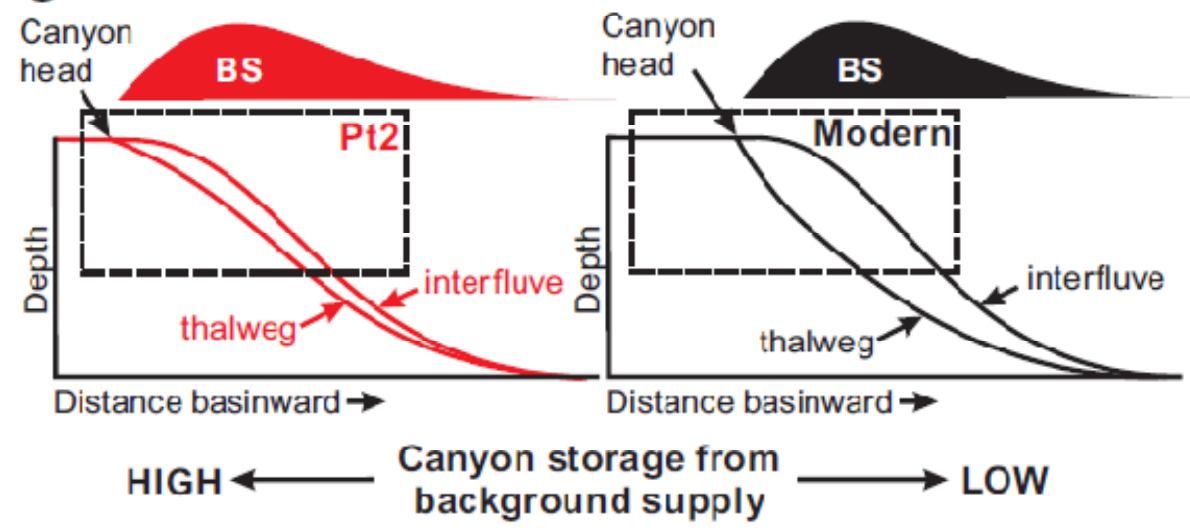

Figure 3. A: Three-dimensional views of mid-Pleistocene (Pt2 horizon) and modern Orpesa Canyon. Black dotted lines show locations of profi les in B. TWT-two-way traveltime. B: Bathymetric profi les along Orpesa thalweg and its bounding interfl uve for Pt2 and modern seafl oor. For time-depth conversion we used function detailed in Urgeles et al. (2010). Mid-Pleistocene profi les were restored to paleobathymetry using backstripping technique. Note change in shape between restored mid-Pleistocene and modern thalweg long profi le from convex-concave to concave up. Note also progressive steepening of intercanyon clinoform from midPleistocene to present. C: Conceptual model for coupled progradation of canyons and interfl uves (based on model presented in Gerber et al., 2009). Long profi les that prograde with equilibrium form have shapes that refl ect dominant source of storage. Interfl uve long-profi le shape refl ects background pattern of sedimentation (BS) while canyon long-profi le shape depends on mix of background and diffusive sedimentation, the latter caused by turbidity currents. 